\title{
Information Communication Technology: A Communication Tool for Women Empowerment
}

\author{
Shivani Jha*, S. K. Kashyap, M. A. Ansari, Pragya Goswamy and Smriti Singh \\ Department of Agricultural Communication, G. B. Pant University of Agriculture \& \\ Technology, Pantnagar, Uttarakhand, India \\ *Corresponding author
}

Keywords

Agriculture

extension, Transfer of technology,

Rural development,

Information and

Communication

Technology,

Sustainable

agriculture

Article Info

Accepted:

08 December 2020

Available Online:

10 January 2021

\begin{abstract}
Agriculture Extension acts as a linking bridge between the research system and farming communities. Agriculture extension has always put efforts in the transfer of technology to the grassroots but faces several limitations. Series of efforts have been made to strengthen the structure and function of agricultural extension setup through innovations. Information and communication technology has emerged as a pertinent tool to provide the latest information within a quick amount of time. Information and Communication Technology (ICT) include technologies that give access to information through communication (Khan et al., 2012). ICT tools provide access to a range of information on market planning, management techniques. It is a powerful tool in the production and marketing system. It affords free access to the vast amount of information, access to market information and the ability to directly access markets. The paper observes that it seems pertinent and essential to rely on ICTs for sustainable agricultural and rural development. Moreover, obvious reasons reveal that information and communication technology has to be adequately entertained to support agricultural extension services to reach up to the grassroots. If utilized systematically, this medium will go a long way in fulfilling the requirements of the formation of knowledge society among villages of the country.
\end{abstract}

\section{Introduction}

Agriculture is the base of Indian economy. About 70 percent population lives in village out of which primarily 47 percent work force is in agriculture (1). Thus, we can say that Indian economy is primarily an agrarian economy. Introduction of new farming technologies like high yielding variety seeds, new implements etc. along with efforts of extension system to disseminate such technologies to farmers ushered green revolution in the country. As a result of green revolution, though India attained selfsufficiency in food grain production, but beyond that many challenges continued to persist like lack of weather updates, lack of market updates, lack of timely and efficient advisory services, low extension agent contact, lack of knowledge of ICT tools etc. Agriculture is a basic driver of economic growth and poverty reduction for many 
developing countries. Agriculture is the largest livelihood provider in community life and occupationally it is highly dependent on various cropping system, animal husbandry and allied sectors (2). Agriculture in India is facing severe challenges like limited land and water availability, which is further exacerbated by degradation of natural resources, climate change, changes in demand and consumption patterns, moving toward high value agriculture, increasing population pressure and liberalization of trade (3). Farmers no longer see agriculture as remunerative enterprise and are migrating for working in industries. ICT tools aims to improve the lives of farm household especially in the rural areas by providing them the appropriate and relevant information.

\section{Role of Farm Women in Agriculture and Constraints faced by them}

Farm women play an important and crucial role in agricultural development. Agriculture sector employs 80 percent of all economically active women out of which 33 percent constitute the agriculture labour force and 48 percent are self-employed (4). Over the years the participation of farm women in agriculture has increased as compared to men.

The agriculture sector in several developing countries is underperforming, partially as a result of lack of accessibility of proper resources to farm women.

A comparison of the different work performed by men and women is presented in table 2 below.

\section{Invisible activities of Rural Women (5)}

"Women comprise, on average, $43 \%$ of the agricultural labour force in developing countries, ranging from $20 \%$ in Latin America to $50 \%$ in Eastern Asia and Sub-Saharan
Africa”. Reducing gender inequalities in access to productive resources and services could increase yields on women's farms by 20-30\%, which could raise agricultural output in developing countries by $2.5-4 \%$, which could in turn reduce the number of hungry people in the world by 12 to 17 percent, or 100 to 150 million people (6). To realize these gains, men and women farmers need access to information, skills and tools to improve yields.

Information and Communication Technology (ICT) can be an effective tool to bridge this gap. Further, the use of ICTs is effective in improving the land use, water management and marketing of the produce. In spite of having access, the use of mobiles and computers by farm women is very less. There could be several plausible reasons for this. This may be because of their weak linkage with outside agencies and knowledge centers due to their less mobility and other social and cultural reasons. The other reasons could be lack of skills and expertise for using the instruments or some restrictions imposed by the male counterparts.

Information and Communication Technology (ICT) is for everyone and women have to be an equal beneficiary to the advantages offered by the technology, and the products and processes, which emerge from its use. The benefits of the information provided by ICT tools, need not be restricted to the upper strata of the society but have to freely flow to all segments of the society.

ICT tools have the potential to reach those women who have not been reached by any other media, thereby empowering them to participate in economic and social progress, and make informed decision. It's necessary to begin utilization of ICT tools in dissemination of information to distantly situated farm women. 
Information and Communication Technologies (ICTs)

Information and Communication Technology (ICT) include technologies that give access to information through communication (7). ICTs in agriculture have the potential to facilitate greater access to information that drive or support knowledge sharing. ICTs essentially facilitate the creation, management, storage, retrieval, and dissemination of any relevant data, knowledge, and information that may have been already processed and adapted (8, $9,10,11)$. ICT as not an individual item like the internet or computers, or telecommunications but as a convergence of different electronic tools that facilitate the functions of information processing and communication, including transmission and display.

Table.1 Percentage of rural male and female workers in agriculture for different years

\begin{tabular}{|l|c|c|c|c|c|c|}
\hline Years & $\mathbf{1 9 7 7 - 7 8}$ & $\mathbf{1 9 8 3 - 8 4}$ & $\mathbf{1 9 8 7 - 8 8}$ & $\mathbf{1 9 9 3 - 9 4}$ & $\mathbf{1 9 9 9 - 0 0}$ & $\mathbf{2 0 0 4 - 0 5}$ \\
\hline Male & 80.7 & 77.8 & 74.6 & 74.1 & 71.3 & 66.5 \\
\hline Female & 88.2 & 87.8 & 84.8 & 86.1 & 85.2 & 83.2 \\
\hline
\end{tabular}

Table.2 Men and Women involved in different activities in agriculture sector

\begin{tabular}{|c|c|c|}
\hline Activities & Women & Men \\
\hline \multirow{5}{*}{$\begin{array}{l}\text { Household } \\
\text { activities }\end{array}$} & Cooking & - \\
\hline & Sweeping, washing clothes and utensils & 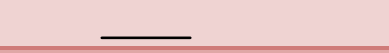 \\
\hline & Fetching water & $\ldots$ \\
\hline & Collecting waste & \\
\hline & Making cow dung cakes & - \\
\hline \multirow[t]{2}{*}{ Child care } & Feeding children & \\
\hline & Taking care of children & 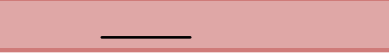 \\
\hline \multirow{7}{*}{$\begin{array}{l}\text { Agricultural } \\
\text { activities }\end{array}$} & Digging & Ploughing, digging \\
\hline & 5 & Irrigation of fields \\
\hline & Harvesting crops & Harvesting crops \\
\hline & Sowing & sowing \\
\hline & Weeding & - \\
\hline & Cutting grass from fields & $=$ \\
\hline & Groundnut picking & \\
\hline \multirow{5}{*}{$\begin{array}{l}\text { Selling and } \\
\text { allied } \\
\text { activities }\end{array}$} & Husking/winnowing & \\
\hline & Vegetable plucking & Vegetable plucking \\
\hline & $\begin{array}{l}\text { Sells vegetables, groundnuts, Occassionally } \\
\text { cereals, sometimes sells fuel wood }\end{array}$ & Occassionally \\
\hline & $\begin{array}{l}\text { Feeding cattle, milking and bathing the cattle } \\
\text { sometimes }\end{array}$ & $\begin{array}{l}\text { Cattle } \\
\text { milking, } \\
\text { cattle }\end{array}$ \\
\hline & Cleaning of cattle shed & $\overline{-}$ \\
\hline
\end{tabular}


Use of ICT to meet the needs of Farm Women

"ICT can be tools that assist them to optimize their production and marketing plans. To make effective use of scarce land by planting for market demand. Use of ICTs to promote the expansion of local markets, and provide direct access for women producers to international markets and productive resources. It provides access to a range of information on likely markets planning, management techniques. It is a powerful tool in production and marketing system. It affords inexpensive access to vast amount of information and networks, access to market information and the ability to directly access lucrative markets.

Telecentres have been established in villages where appropriate rural female farmers can tap these resources and access information using new ICTs, such as e-mail, the World Wide Web, electronic networks, teleconferencing, and distance-learning tools.

Information can empower rural female farmers to participate in decision-making, exchange ideas with others in developed and developing countries, and improve the quality of life of the people. The internet, email and wireless mobile phone can empower these women by offering access to services unavailable to them because of high cost in the rural areas. In Grameen phone (used in Bangladesh) ladies benefit for timely access to marketing process for agricultural products or handicrafts" (12).

\section{Advantages of ICT}

Applications of ICT in various sectors offer many advantages. The important advantages are save manpower, eliminate human errors, enable faster communication and exchange of ideas, save time, avoid duplication efforts, improve quality, enable total automation, improve the way of working, increase productivity, create and expand markets and grow economy.

There are some more advantages of ICTs in agricultural development:

The online services can be provided through the ICT for information, education, training, consultation, diagnosis, monitoring, transaction and processing.

ICT can be helpful in facilitating the interaction among the researchers, extension workers and farmers.

ICT can provide a question and answer services. Here, experts respond to the queries on the specialized subjects.

ICT helps in providing up-to-date information services to farmers such as market information, weather forecasting, input supply, credit availability, etc.

ICT helps in creation of database of local resources of villages and the villagers, site specific information system, expert system etc.

ICT helps in providing information services on disease/pest early warning system, information regarding rural development programmes, crop insurance and post-harvest technology.

ICT helps in facilitation of land records and online registration services.

ICT helps in improving the marketing of milk and milk products.

ICT provides tele-education to farmers.

ICT can extend services regarding farm business and management information to the farmers.

In conclusion looking into the above perspective it seems pertinent and essential to rely on ICT tools for sustainable agricultural, rural development and women empowerment. Information and communication technology has to be adequately entertained to support 
agriculture extension services to reach up to the grassroots. ICT tools provide access to a range of information on market planning, management techniques. It is a powerful tool in production and marketing system. Researches have revealed that this medium has been effectively utilized for information dissemination, information sharing, bottom to top communication, catering to knowledge empowerment of marginalized segments as well as on gender issues. If utilized systematically, this medium will go a long way in fulfilling the requirements of formation of knowledge society among villages of the country and give latest information to women farmers.

\section{Application of review}

Useful to understand the vast potential and scope of Information and communication technology in strengthening agriculture extension, which has immense role in agricultural and rural development. Moreover, the review also highlights that for women empowerment and agriculture \& rural development, participation of beneficiaries and realization of their needs by the change agency is of utmost importance.

\section{References}

1. FAO/MAF, 2010. National Gender Profile of Agricultural Households, 2010. Report based on the Lao Expenditure and Consumption Surveys, National Agricultural Census and the National Population Census. Food and Agriculture Organization of the United Nations, Rome and Ministry of Agriculture and Forestry, Vientiane.

2. Mishra, R.P. and Sundaram, K.V. 1970. Rural Area Development Perspective and Approaches, Sterling Publication.

3. Lele, S., Wilshusen, P., Brockington, D., Seidler, R. and Bawa, K. 2010. Beyond exclusion: alternative approaches to biodiversity conservation in the developing tropics. Current Opinion in Environmental Sustainability, 2(2): 94100.

4. OXFAM. 2018. Move over 'Sons of the soil': Why you need to know the female farmers that are revolutionizing agriculture in India. Briefing Paper. Accessed on 7 January, 2020. https://www.oxfamindia.org/womenempowerment-india-farmers.

5. Chowdhry, S. 2004. Invisible Activities of Rural Women. Kurukshetra, 52(9): 2228.

6. FAO (Food and Agriculture Organization). 2011. The State of Food and Agriculture, 2010-2011. Women in Agriculture: Closing the Gender Gap for Development.

7. Khan, M. S. H., Hasan, M. and Clement, C. K. 2012. Barriers to the introduction of ICT into education in developing countries: The example of Bangladesh. International Journal of instruction, 4(2): 14-21

8. Batchelor, S. 2002. Using ICTs to Generate Development Content. IICD Research Report 10. The Hague: International Institute for Communication and Development.

9. Chapman, R. and Slaymaker, T. 2002. ICTs and Rural Development: Review of the Literature, Current Interventions, and Opportunities for Action. ODI Working Paper 192. London: Overseas Development Institute.

10. Rao, N. H. 2007. A Framework for Implementing Information and Communication Technologies in Agricultural Development in India. Technological Forecasting and Social Change, 7(5): 491-518.

11. Heeks, R. 2002. - Information Systems and Developing Countries: Failure, Success and Local Improvisations. The 
Information Society, 18(4): 101-112.

12. Sharma, S. and Maheshwari, S. 2015. Use of ICT by farm women: A step towards empowerment. Indian Research Journal of Extension Education, 15(3): 60-65.

\section{How to cite this article:}

Shivani Jha, S. K. Kashyap, M. A. Ansari, Pragya Goswamy and Smriti Singh. 2021. Information Communication Technology: A Communication Tool for Women Empowerment. Int.J.Curr.Microbiol.App.Sci. 10(01): 578-583. doi: https://doi.org/10.20546/ijcmas.2021.1001.070 